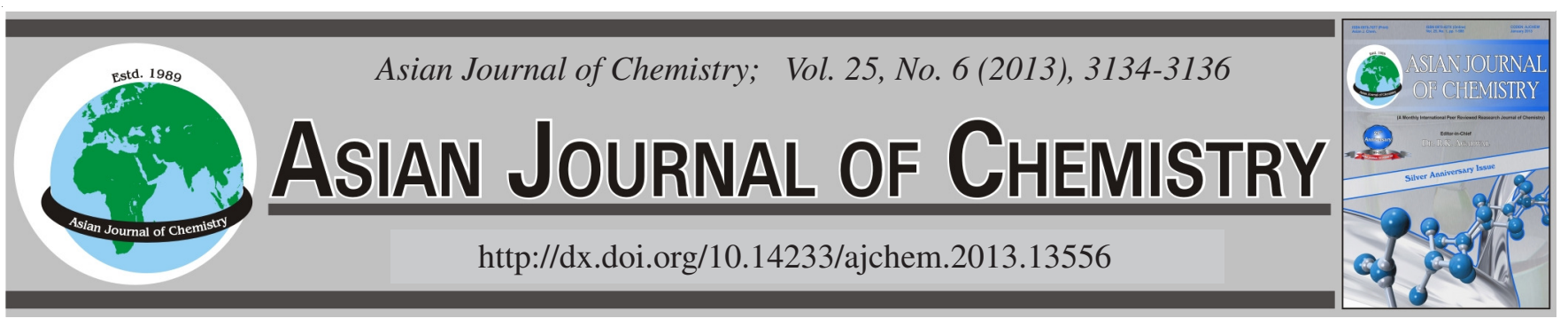

\title{
Synthesis, Crystal Structure and Fluorescence Property of Iron(II) Complex $\left[\mathrm{Fe}(\text { phen })_{3}\right]\left(\right.$ pydc) $\cdot 9 \mathrm{H}_{2} \mathrm{O}$
}

\author{
Shu-Yang Chen ${ }^{*}$, Hong-Xian Sun, Ying-Chen Guo and Feng-Pu CaO
}

College of Chemistry and Pharmacy Engineering, Nanyang Normal University, Nanyang 473061, P.R. China

*Corresponding author: E-mail: shuyang@nynu.edu.cn

\begin{abstract}
A new iron(II) complex, $\left[\mathrm{Fe}(\text { phen })_{3}\right]\left(\right.$ pydc) $\cdot 9 \mathrm{H}_{2} \mathrm{O}$, has been synthesized by the reaction of ferrous sulfate, 2,6-pyridine dicarboxylic acid $\left(\mathrm{pydcH}_{2}\right)$ and 1,10-phenanthroline (phen) and characterized by elemental analysis, IR, TG and X-ray single-crystal diffraction. It crystallizes in monoclinic, space group $\mathrm{C} / 2 \mathrm{c}$, with $\mathrm{a}=28.477(8), \mathrm{b}=19.042(5), \mathrm{c}=20.861(8) \AA, \beta=129.52(2), \mathrm{V}=8726(5) \AA^{3}, \mathrm{C}_{43} \mathrm{H}_{45} \mathrm{FeN}_{7} \mathrm{O}_{13}, \mathrm{M}_{\mathrm{r}}$ $=923.57, \mathrm{Z}=8, \mathrm{Dc}=1.379 \mathrm{Mg} / \mathrm{m}^{3}, \lambda\left(\mathrm{MoK}_{\alpha}\right)=0.71073 \AA, \mu=0.418 \mathrm{~mm}^{-1}, \mathrm{~F}(000)=3712, \mathrm{~S}=1.062$, the final $\mathrm{R}=0.0624$ and $\mathrm{wR}=$ 0.2083 for 5540 observed reflections (I $>2 \sigma(\mathrm{I})$ ). The Fe(II) is coordinated with six nitrogen atoms from three 1,10-phenanthroline molecules making a distorted octahedron $\left[\mathrm{Fe}(\mathrm{phen})_{3}\right]^{2+}$ and a pydc $\mathrm{cos}^{2-}$ as a counter anion. A two-dimensional layer structure is constructed by the interactions between $\left[\mathrm{Fe}(\mathrm{phen})_{3}\right]^{2+}$ and $\mathrm{pydc}^{2-}$. Fluorescence spectral analysis shows that the complex has a fluorescence-emission at around $360 \mathrm{~nm}(\mathrm{CCDC}: 822144)$.
\end{abstract}

Key Words: Iron complex, Crystal structure, Fluorescence property.

\section{INTRODUCTION}

Exploration on the syntheses and properties of metal coordination complexes, especially carboxylate complexes, has been one of the most active research areas of materials due to their interesting properties and various potential applications, such as electrical conductivity, magnetism, host-guest chemistry, ion exchange, catalysis and non-linear optics ${ }^{1-3}$. Pyridine dicarboxylic acid $\left(\mathrm{pydcH}_{2}\right)$ is an active ligand not only for its multivariate coordination modes with transition metals and rare metals, but also for its biological activities in organism, so its complexes are widely studied and used in the fields of biochemistry and analytical chemistry ${ }^{4-6} .1,10$-Phenanthroline (phen) is another widely used ligand and most of its complexes with metals exhibit novel structures or specific properties ${ }^{7-9}$. As part of our works, a new iron complex with pyridine dicarboxylic acid and 1,10-phenanthroline (phen) ligands was obtained by using solvent evaporation method. Here we report the synthesis, crystal structure, thermal stability and fluorescence property of the complex $\left[\mathrm{Fe}(\text { phen })_{3}\right]($ pydc $) \cdot 9 \mathrm{H}_{2} \mathrm{O}$.

\section{EXPERIMENTAL}

Ferrous sulfate, 1,10-phenanthroline (phen) and $\mathrm{NaOH}$ were of analytically pure grade and the purity of 2,6-pyridine dicarboxylic acid was $99 \%$. Elemental analyses (C, H and N) were performed on Vario E1 elementar. Infrared spectra were recorded on a Nicolet 5700 FT-IR spectrophotometer (4000$400 \mathrm{~cm}^{-1}$ ) using $\mathrm{KBr}$ pellets. Thermogravimetric analysis was carried out on a Netzsch STA 449C thermal analyzer in flowing $\mathrm{N}_{2}$ atmosphere at a heating rate of $10^{\circ} \mathrm{C} / \mathrm{min}$ from room temperature to $850{ }^{\circ} \mathrm{C}$. The fluorescence property of the complex was tested using a CARY Eclipse fluorescence spectroscopy.

Synthesis of the title complex: 2,6-Pyridine dicarboxylic acid $(1 \mathrm{mmol})$, phen $(1 \mathrm{mmol})$ and $\mathrm{NaOH}(2 \mathrm{mmol})$ were dissolved in $20 \mathrm{~mL}$ mixed solvent of $\mathrm{C}_{2} \mathrm{H}_{5} \mathrm{OH} / \mathrm{H}_{2} \mathrm{O}$ by stirring and $\mathrm{FeSO}_{4} \cdot 7 \mathrm{H}_{2} \mathrm{O}(1 \mathrm{mmol})$ in $10 \mathrm{~mL} \mathrm{H}_{2} \mathrm{O}$ was added slowly and further stirred for $3 \mathrm{~h}$ at room temperature. The resulting solution was filtered and the filtrate was kept at room temperature for two weeks. Red block crystals (yield $62 \%$ ) suitable for X-ray diffraction were obtained. Anal. calcd. (\%) for $\mathrm{C}_{43} \mathrm{H}_{45} \mathrm{~N}_{7} \mathrm{O}_{13} \mathrm{Fe}$ : Calcd. (\%): C, 55.94; H, 4.87; N, 10.61. Found (\%): C, 55.82; H, 4.80; N, 10.55. IR (KBr, $\left.v_{\max }, \mathrm{cm}^{-1}\right): 3431 \mathrm{~s}$, 1672 s, 1515 w, 1423 w, 1320 s, 1165 m, 1071 w, 912 w, 740 w, $679 \mathrm{~m}, 438 \mathrm{w}$.

X-ray crystallographic determination: A suitable crystal with dimensions of $0.23 \mathrm{~mm} \times 0.18 \mathrm{~mm} \times 0.15 \mathrm{~mm}$ was used for structure determination. All diffraction data were collected at 293(2) K on a Bruker SMART APEX-II CCD diffractometer equipped with a graphite-monochromated $\mathrm{MoK}_{\alpha}$ radiation $(\lambda$ $=0.71073 \AA$ ) by using a $\phi-\omega$ scan mode. In the range of 1.97 $<\theta<25.00^{\circ}$, a total of 21880 reflections together with 7689 unique ones $\left(\mathrm{R}_{\mathrm{int}}=0.0294\right)$ were collected and 5540 observed 
TABLE-1

SELECTED BOND LENGTHS $(\AA)$ AND BOND ANGLES $\left(^{\circ}\right) \mathrm{OF}\left[\mathrm{Fe}(\text { phen })_{3}\right]($ pydc $) \cdot 9 \mathrm{H}_{2} \mathrm{O}$

\begin{tabular}{lc|cc|cc}
\hline Bond & Dist. & Bond & Dist. & Bond & Dist. \\
\hline $\mathrm{Fe}(1)-\mathrm{N}(1)$ & $1.980(3)$ & $\mathrm{Fe}(1)-\mathrm{N}(3)$ & $1.978(3)$ & $\mathrm{Fe}(1)-\mathrm{N}(5)$ & $1.983(3)$ \\
$\mathrm{Fe}(1)-\mathrm{N}(2)$ & $1.971(3)$ & $\mathrm{Fe}(1)-\mathrm{N}(4)$ & $1.986(3)$ & $\mathrm{Fe}(1)-\mathrm{N}(6)$ & $1.979(3)$ \\
\hline Angle & $\left({ }^{\circ}\right)$ & Angle & $\left({ }^{\circ}\right)$ & Angle & $\left({ }^{\circ}\right)$ \\
\hline $\mathrm{N}(1)-\mathrm{Fe}(1)-\mathrm{N}(2)$ & $82.49(13)$ & $\mathrm{N}(2)-\mathrm{Fe}(1)-\mathrm{N}(3)$ & $172.01(12)$ & $\mathrm{N}(3)-\mathrm{Fe}(1)-\mathrm{N}(5)$ & $94.48(12)$ \\
$\mathrm{N}(1)-\mathrm{Fe}(1)-\mathrm{N}(3)$ & $92.13(13)$ & $\mathrm{N}(2)-\mathrm{Fe}(1)-\mathrm{N}(4)$ & $91.47(13)$ & $\mathrm{N}(3)-\mathrm{Fe}(1)-\mathrm{N}(6)$ & $90.11(13)$ \\
$\mathrm{N}(1)-\mathrm{Fe}(1)-\mathrm{N}(6)$ & $176.50(12)$ & $\mathrm{N}(2)-\mathrm{Fe}(1)-\mathrm{N}(5)$ & $91.88(12)$ & $\mathrm{N}(4)-\mathrm{Fe}(1)-\mathrm{N}(5)$ & $174.53(12)$ \\
$\mathrm{N}(1)-\mathrm{Fe}(1)-\mathrm{N}(4)$ & $89.83(13)$ & $\mathrm{N}(2)-\mathrm{Fe}(1)-\mathrm{N}(6)$ & $95.55(12)$ & $\mathrm{N}(4)-\mathrm{Fe}(1)-\mathrm{N}(6)$ & $93.13(13)$ \\
$\mathrm{N}(1)-\mathrm{Fe}(1)-\mathrm{N}(5)$ & $94.89(13)$ & $\mathrm{N}(3)-\mathrm{Fe}(1)-\mathrm{N}(4)$ & $82.57(13)$ & $\mathrm{N}(5)-\mathrm{Fe}(1)-\mathrm{N}(6)$ & $82.24(13)$ \\
\hline
\end{tabular}

reflections with $\mathrm{I}>2 \sigma(\mathrm{I})$ were used in the succeeding refinements. The structure was solved by direct methods using SHELXS-97 program $^{10}$ and refined with SHELXL-9 ${ }^{11}$ by fullmatrix least-squares techniques on $\mathrm{F}^{2}$. The hydrogen atoms of isolated water molecules in complex were not added. All nonhydrogen atoms were refined anisotropically and hydrogen atoms isotropically by full-matrix least-squares refinement. The final cycle of refinement converged to $\mathrm{R}=0.0624$ and $\mathrm{wR}=0.2083\left(\mathrm{w}=1 /\left[\sigma^{2}\left(\mathrm{~F}_{\mathrm{o}}{ }^{2}\right)+(0.1432 \mathrm{P})^{2}+8.0727 \mathrm{P}\right]\right.$, where $\left.\mathrm{P}=\left(\mathrm{F}_{\mathrm{o}}^{2}+2 \mathrm{~F}_{\mathrm{c}}^{2}\right) / 3\right),(\Delta / \sigma)_{\max }=0.001,(\Delta \rho)_{\max }=1.245$ and $(\Delta \rho)_{\min }$ $=-0.390 \mathrm{e} / \AA^{3}$.

\section{RESULTS AND DISCUSSION}

IR spectrum: In the IR spectrum, a strong and wide absorption bond around $3431 \mathrm{~cm}^{-1}$ is the characteristic vibration of water. There is no absorption bond in the range of 1690$1730 \mathrm{~cm}^{-1}$ indicating the completely unprotonated of carboxyl ${ }^{12}$. Bands at 1672 and $1320 \mathrm{~cm}^{-1}$ could be attributed to the stretching vibration of carboxylate groups. Bonds at 1515 and $1423 \mathrm{~cm}^{-1}$ could be assigned to the characteristic of phen. The shift in some extent suggests that the two nitrogen atoms of phen both have participated in coordination.

Crystal structure: The crystal structure and packing diagram of the complex are shown in Figs. 1 and 2, respectively. The selected bond lengths and bond angles are listed in Table- 1 .

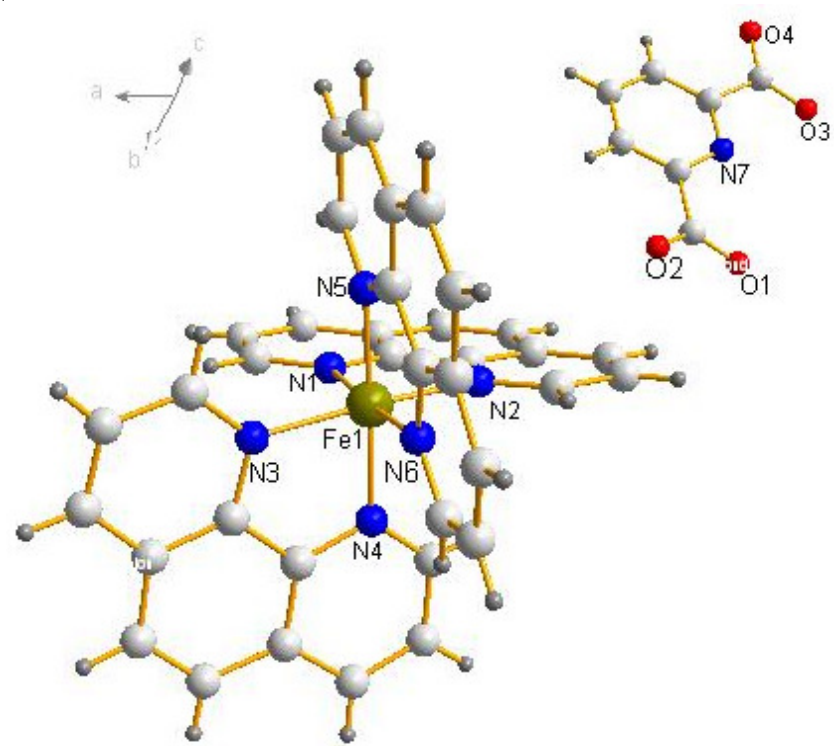

Fig. 1. Molecular structure of $\left[\mathrm{Fe}(\mathrm{phen})_{3}\right]($ pydc $) \cdot 9 \mathrm{H}_{2} \mathrm{O} ;\left(\mathrm{H}_{2} \mathrm{O}\right.$ molecules have been omitted for clarity)
$\mathrm{X}$-ray analysis reveals that the complex, $\left[\mathrm{Fe}(\text { phen })_{3}\right]($ pydc $) \cdot 9 \mathrm{H}_{2} \mathrm{O}$, crystallizes in monoclinic system with space group $\mathrm{C} / 2 \mathrm{c}$ and the sturcture unit consists of one $\left[\mathrm{Fe}(\text { phen })_{3}\right]^{2+}$ cation, one pydc ${ }^{2-}$ anion and nine crystal water molecules (Fig. 1). The Fe(II) is coordinated with six nitrogen atoms from three phen molecules and a pydc ${ }^{2-}$ as a counter anion. In the 6-coordinated octahedron, N(1), N(2), N(3) and $\mathrm{N}(6)$ locate at the equatorial plane and $\mathrm{N}(4)$ and $\mathrm{N}(5)$ occupy the axial positions. The six Fe-N bond lengths are in the range of 1.971(3)-1.986(3) $\AA$ and these are similar to that in $\left[\mathrm{Fe}(\text { phen })_{3}\right]\left(\mathrm{C}_{5} \mathrm{H}_{4} \mathrm{COC}_{6} \mathrm{H}_{5}\right)_{2} \mathrm{CH}_{3} \mathrm{CN} \cdot 2 \mathrm{H}_{2} \mathrm{O}^{13}$ and $\left[\mathrm{Fe}(\text { phen })_{3}\right]$ $\left(\mathrm{C}_{6} \mathrm{H}_{6} \mathrm{~N}_{2} \mathrm{~S}_{2} \mathrm{O}_{6}\right) \cdot 4 \mathrm{H}_{2} \mathrm{O}^{14}$. Bond angles of $\mathrm{N}(1)-\mathrm{Fe}(1)-\mathrm{N}(2), \mathrm{N}(2)-$ $\mathrm{Fe}(1)-\mathrm{N}(6), \mathrm{N}(6)-\mathrm{Fe}(1)-\mathrm{N}(3)$ and $\mathrm{N}(3)-\mathrm{Fe}(1)-\mathrm{N}(1)$ are 82.49(13), 95.55(12), 90.11(13) and 92.13(13) ${ }^{\circ}$, respectively. The sum of these angles is $360.28^{\circ}$ (close to $360^{\circ}$ ), suggesting a planar nature of $\mathrm{N}(1), \mathrm{N}(2), \mathrm{N}(3), \mathrm{N}(6)$ and $\mathrm{Fe}(1)$. Bond angle of $\mathrm{N}(4)-\mathrm{Fe}(1)-\mathrm{N}(5)$ is $174.53^{\circ}$. The dihedral angles between the each phen molecules are 89.21, 84.61 and $87.0^{\circ}$, respectively. A two-dimensional layer structural system is formed by the interactions between $\left[\mathrm{Fe}(\text { phen })_{3}\right]^{2+}$ cation and uncoordinated pydc $^{2-}$ anion and is filled with isolated water molecules between the layers (Fig. 2).

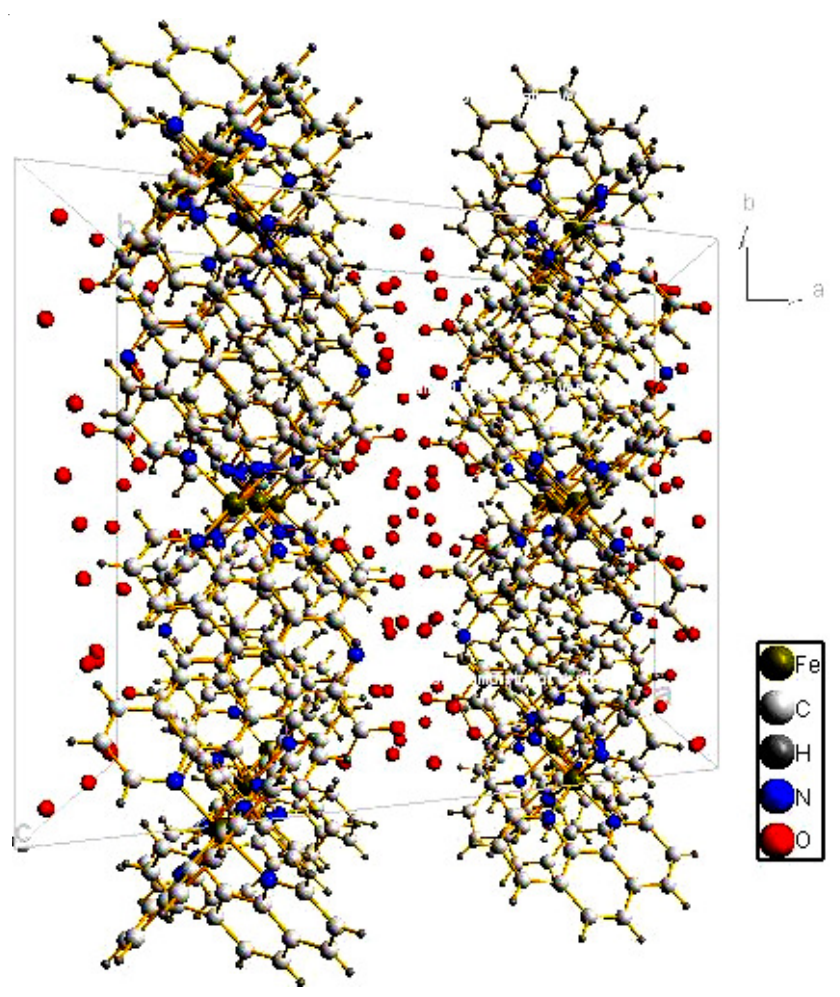

Fig. 2. Packing diagram of $\left[\mathrm{Fe}(\text { phen })_{3}\right]($ pydc $) \cdot 9 \mathrm{H}_{2} \mathrm{O}$ along $\mathrm{c}$ axis 
Thermogravimetric analysis: The thermal stability of the complex was investigated under the thermogravimetric experiment. The weight loss before $135^{\circ} \mathrm{C}$ is $16.7 \%$, with a maximal endothermic peak appears at $84^{\circ} \mathrm{C}$, this can be attributed to the elimination of the nine crystal water molecules (cacld. $17.5 \%$ ). Then obvious weight loss with two endothermic peak at about 320 and $428{ }^{\circ} \mathrm{C}$ indicates the framework of the complex begin to collapse.

Fluorescence spectrum: The fluorescence of the complex and the ligands in methanol solution was investigated at room temperature (Fig. 3). The excitation and emission silts are both $10 \mathrm{~nm}$. At the excitation wavelength of $240 \mathrm{~nm}$, the maximum fluorescence emission wavelengths of the complex is $360 \mathrm{~nm}$ and the spectral shape and position are similar to that of phen ligand, suggests that the fluorescence of the complex mainly coming from phen. This emission spectrum may have relationship with the rigid structure and big conjugate system of 1,10-phenanthroline ${ }^{15}$.

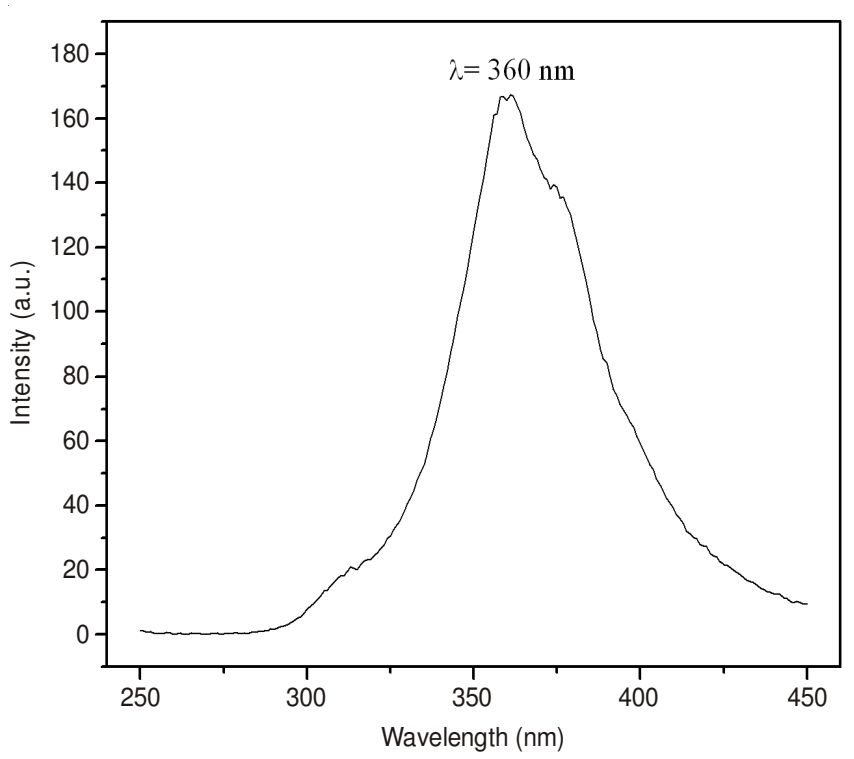

Fig. 3. Excitation spectrum of the complex

\section{Conclusion}

In summary, a new iron(II) complex $\left[\mathrm{Fe}(\text { phen })_{3}\right]$ (pydc) $.9 \mathrm{H}_{2} \mathrm{O}$ was synthesized and confirmed successfully. The results show that the 6-coordinated geometry of the central iron(II) is a distorted octahedron and a two-dimensional layer structural system is formed by the interactions between $\left[\mathrm{Fe}(\text { phen })_{3}\right]^{2+}$ cation and uncoordinated pydc ${ }^{2-}$ anion. The complex shows a fluorescence emission at around $360 \mathrm{~nm}$ in methanol solution.

\section{ACKNOWLEDGEMENTS}

The authors are grateful to Foundation of Henan Science and Technology Department (No. 092102210216, 112300410224) and the Natural Science Foundation of Henan Education Department (2011B150025) supporting this study.

\section{REFERENCES}

1. O.M. Yaghi, M. O'Keeffe, N.W. Ockwig, H.K. Chae, M. Eddaoudi and J. Kim, Nature, 423, 705 (2003).

2. S. Kitagawa, R. Kitaura and S.I. Noro, Angew. Chem., Ind. Ed., 43, 2334 (2004).

3. H. Deng, C.J. Doonan, H. Furukawa, R.B. Ferreira, J. Towne, C.B. Knobler, B. Wang and O.M. Yaghi, Science, 327, 846 (2010).

4. D.C. Crans, L. Yang, T. Jakusch and T. Kiss, Inorg. Chem., 39, 4409 (2000).

5. X.-J. Sun, J.-F. Zhou and M.-Z. Yan, Chin. J. Inorg. Chem., 25, 1483 (2009).

6. S.-Y. Chen, Y.-C. Guo, J.-W. Yan and Y.-Q. Feng, Chin. J. Struct. Chem., 30, 1064 (2011).

7. D.Y. Wu, O. Sato and C.Y. Duan, Inorg. Chem. Comm., 12, 325 (2009).

8. M.-Q. Dong, L. Song, C. Ling and K. Xue, Asian J. Chem., 25, 1003 (2013).

9. Y.-S. Yang, W.-X. Chai, L. Song, H.-S. Shi and L.-S. Qin, Asian J. Chem., 24, 5368 (2012).

10. G.M. Sheldrick, SHELXS 97, Program for Crystal Structure Solution; University of Göttingen: Göttingen, Germany (1997).

11. G.M. Sheldrick, SHELXL 97, Program for Crystal Structure Refinement; University of Göttingen: Göttingen, Germany (1997).

12. J. Dai, J. Yang and J.-T. Li, Chin. J. Inorg. Chem., 26, 176 (2010).

13. D.-J. Che, G. Li, B.-S. Du, Z. Zhang and Y.-H. Li, Inorg. Chim. Acta, 261, 121 (1997).

14. M.-L. Huang, Z.-Y. Lin, Y.-S. Su, L.-R. Li, Z.-L. Li and F.-L. Xiao, Chin. J. Shangqiu Teachers College, 27, 41 (2011).

15. F.-Y. Bai, X. Lü, S.-Q. Liu and X.-T. Li, Chin. J. Inorg. Chem., 27, 1261 (2011). 